\title{
Neotropical Deer Ked or Neotropical Deer Louse Fly, Lipoptena mazamae Rondani ${ }^{1}$
}

William H. Kern, Jr. ${ }^{2}$

\section{Introduction}

The Neotropical deer ked is a common ectoparasite of the white-tailed deer (Odocoileus virginianus) in the southeastern United States. The louse flies (Hippoboscidae) are obligate blood-feeding ectoparasites of birds and mammals. Both adult males and females feed on the blood of their host. They are adapted for clinging to and moving through the plumage and pelage of their hosts. Strongly specialized claws help them cling to the hair or feathers of their particular host species. Deer keds have wings when they emerge from their puparium, but lose their wings once they find a host (deer).

\section{Distribution}

This fly is an obligate parasite of white-tailed deer and red brocket deer (Mazama americana). It occurs on white-tailed deer throughout Florida and the southeastern United States north at least to Virginia and Oklahoma (Kocan 2003) and south through Panama in Central America and as far south as northeastern Brazil (Neotropical and southern
Nearctic regions) (Bequaert 1942). It also occurs on red brocket deer from Mexico to northern Argentina (Bequaert 1942).

\section{Identification}

Neotropical deer keds are brown, dorso-ventrally flattened flies that live in the pelage of deer (Figure 1 and 2). It is the only deer ked currently found on white-tailed deer in the southeastern United States. They are often misidentified as ticks by hunters, but can be identified as insects because they have 6 legs and 3 body regions (head, thorax and abdomen). The winged flies are rarely seen becuse they lose their wings soon after finding a host (Figure 3). Females are larger than males (females 3.5-4.5 $\mathrm{mm}$ and male 3 $\mathrm{mm}$ head and body length). They have a tough exoskeleton that protects them from being crushed by the grooming host and this adds to the perception that these are ticks. They are larger than most lice and move faster than either ticks or lice.

1. This document is ENY-686, one of a series of the Entomology and Nematology Department, Florida Cooperative Extension Service, Institute of Food and Agricultural Sciences, University of Florida. First printed September 2003. Please visit the EDIS Website at http://edis.ifas.ufl.edu.

2. William H. Kern, Jr., Assistant Professor, Entomology and Nematology, Ft. Lauderdale Research and Education Center, University of Florida, Davie, FL 33314.

The use of trade names in this publication is solely for the purpose of providing specific information. UF/IFAS does not guarantee or warranty the products named, and references to them in this publication does not signify our approval to the exclusion of other products of suitable composition. Use pesticides safely. Read and follow directions on the manufacturer's label.

The Institute of Food and Agricultural Sciences is an equal opportunity/affirmative action employer authorized to provide research, educational information and other services only to individuals and institutions that function without regard to race, color, sex, age, handicap, or national origin. For information on obtaining other extension publications, contact your county Cooperative Extension Service office. Florida Cooperative Extension Service/Institute of Food and Agricultural Sciences/University of Florida/Christine Taylor Waddill, Dean. 


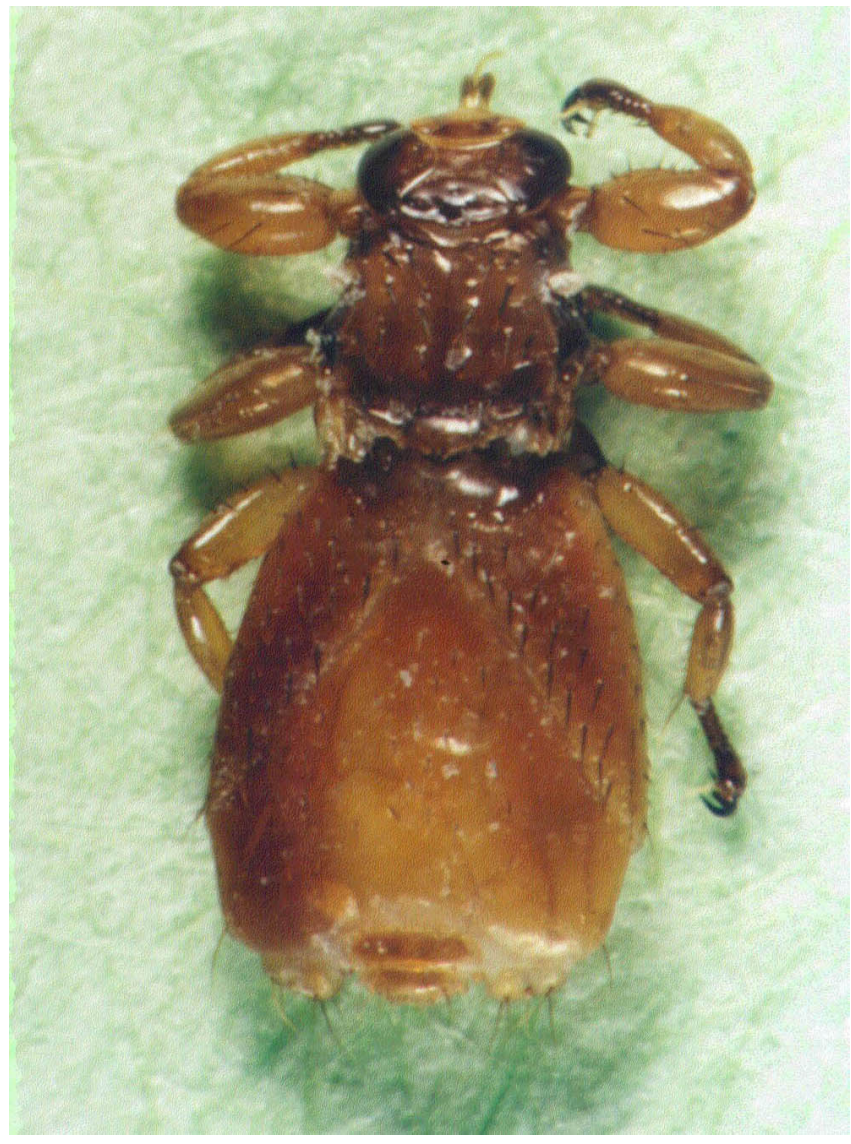

Figure 1. Dorsal view of female Lipoptena mazamae, collected from white-tailed deer in Collier Co., FL. Credits: Karen Wheeler / University of Florida - Ft. Lauderdale R.E.C.

\section{Life Histories and Habitat}

Deer keds have a very interesting reproductive strategy. The female produces one larva at a time and retains the developing larva in her body until it is ready to pupate. The larva feed on the secretions of a "milk gland" in the uterus of its mother. After three larval molts, the larva has reached its maximum size, the mother gives birth to the white pre-pupa which immediately begins to darken and form the puparium or pupal shell. The pupae fall from the deer and are usually deposited where the deer bed. When the fly has completed its development, the winged adult emerges from the puparium and flies in search of a host. After finding a host the adult fly breaks off its wings and is now permanently associated with that one deer. Both sexes feed on the blood of the host deer.

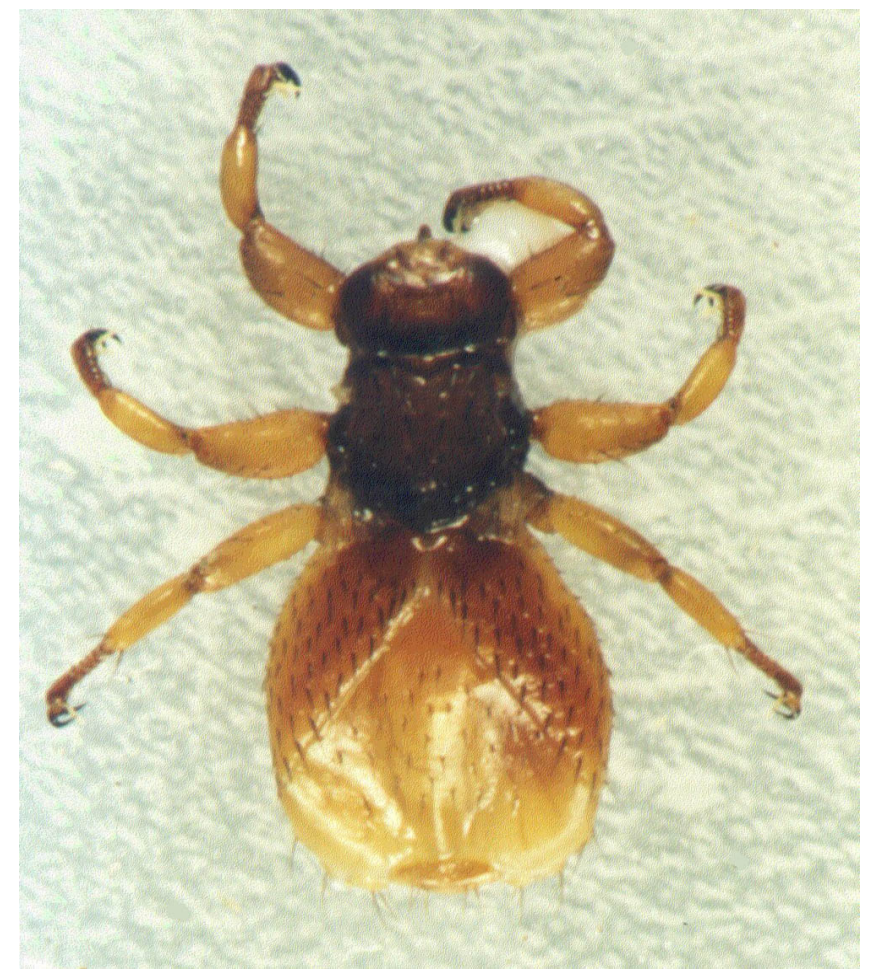

Figure 2. Dorsal view of male Lipoptena mazamae, collected from white-tailed deer in Collier Co., FL. Credits: Karen Wheeler / University of Florida - Ft. Lauderdale R.E.C.

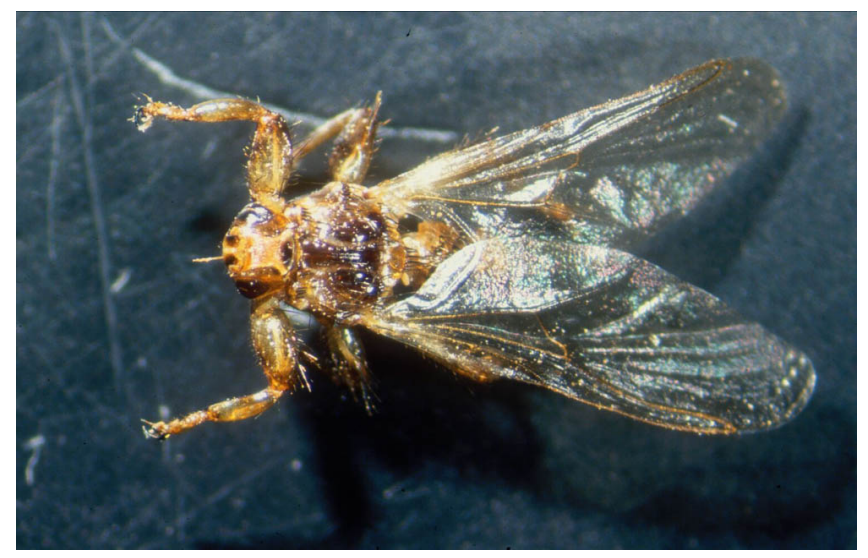

Figure 3. Young Lipoptena cervi, a related species, prior to losing its wings. Credits: Steve Jacobs, Pennsylvania State University

\section{Hosts}

This fly is an obligate parasite of New World deer. It has been collected on white-tailed deer (Odocoileus virginianus) from the southeastern United States to Brazil (Bequaert 1942) and red brocket deer (Mazama americana) from Mexico and Central America (Wenzel and Tipton, 1966) to northern Argentina (Bequaert 1942). In ectoparasite studies conducted by Donald J. Forrester and Sam R. 
Telford, Jr., they found that $84 \%$ of 237 deer sampled from 1984 to 1989 in Collier County, Florida were infested with neotropical deer keds and $31 \%$ of 26 deer sampled in 1988 and 1989 in Monroe and Dade County, Florida were infested (Forrester 1992). Two bucks ( $31 / 2$ and $11 / 2$ years old) were examined in Collier County, FL in October 2001 and both harbored large populations (>50) of wingless adult flies. A doe (1 1/2 years old) was examined in Calhoun County, FL in November 2002 and had over one hundred adult flies in the pelage on its neck, flanks and belly (Kern, personal obs.).

\section{Medical and Veterinary Importance}

No parasites, predators, or diseases have been described from the Neotropical deer ked on white tailed deer. They are not known to transmit any disease to deer or humans. Hunters dressing harvested deer are likely to encounter these flies and possibly may be bitten.

\section{Selected References}

Bequaert, J. 1942. A monograph of the Melophaginae, or ked-flies, of sheep, goats, deer and antelopes (Diptera, Hippoboscidae). Entomologica Americana 22(2): 65-220.

Davidson, W. R. and V. F. Nettles. 1997. Field manual of wildlife diseases in the Southeastern United States. Second edition. Southeastern Cooperative Wildlife Disease Study, The University of Georgia, Athens, GA. 417 pp.

Forrester, D. J. 1992. Parasites and diseases of wild mammals in Florida. University Press of Florida, Gainesville, FL. 460 pp.

Kocan, A. A. 2003. Parasitic and infectious diseases of white-tailed deer in Oklahoma. http://www.cvm.okstate.edu/instruction/kocan/ vpar5333/deerpar.htm.

Maa, T. C. 1965. A synopsis of the Lipopteninae. J. Med. Entomol. 2 (3): 233-248.

Strickland, R.K., R.R. Gerrish, and J. S. Smith. 1981. Chapter 24. Arthropods. In Diseases and parasites of white-tailed deer. Edited by Davidson,
W. R. et al. Misc. Publication No. 7 of the Tall Timbers Research Station, Tallahassee, FL. P. 376-377.

Theodor, O. 1975. Diptera pupipara; Fauna Palaestina-Insecta I. The Israel Academy of Sciences and Humanities, Jerusalem, Israel. 170 pp.

Wenzel, R. L. and V. J. Tipton. 1966.

Ectoparasites of Panama. Field Museum of Natural History, Chicago, IL. p. 390.

Photos by Ms. Karen Wheeler / UF-Ft. Lauderdale R.E.C. 